\title{
New and innovative consumer demands and expectations on the Hungarian food market
}

\author{
MÁRIA TÖRŐCSIK - ESZTER PÁL - ESZTER JAKOPÁNECZ
}

University of Pécs, Faculty of Business and Economics, Institute of Marketing and

Tourism, Pécs, Hungary

torocsik@ktk.pte.hu

\section{Summary}

Food and eating have always encompassed more than the simple intake of nutrients; therefore, when thinking about food consumption, we need to examine several groups of influencing factors whose correlations from the aspect of the consumer are described by a complicated matrix. This paper focuses on the selection of signs indicating new and innovative consumer behaviours, and on the megatrends that are the driving forces of transitions and that lead to the consequences of strikingly reconsidered consumer decisions nowadays. The authors stress that there are qualitative and structural changes in food consumption in Hungary, with an increasing quantity of differentiated consumer demands appearing, a few of them influencing our everyday decisions even at the concept level. The findings of primary research originated from a personal questionnaire survey consisting of 2001 respondents, in which we also focused on the attitude towards eating and media consumption related to gastronomy.

This paper is an introduction to the market segments detectable in the present Hungarian population aged 15-74 in the topics concerned.

Keywords: food consumption behaviour, food consumption trends, gastro-media consumption

\section{Introduction}

The study of food and eating is an issue during the analysis of any segment of which we find several imprints of the lives of the people living in the respective time. Foods have an outstanding significance, in addition to experiencing everyday routine, in the appearance of the wellbeing, of satisfaction. If we focus on the nutrition behaviour and the shopping decisions of a group, we can see their position in society, their values, the relationships that they have towards each other, the frameworks determining their decisions, their lifestyle and the contents and emotions communicated with foods (Karmasin, 2001). The consumption of foods also has a huge impact on the economy, just think of the fact that the second largest proportion of the expenditure of households is in this area, with an average value of $24.1 \%$ in 2016 in 
Hungary, measured by the Hungarian Central Statistical Office, HCSO (HCSO, 2017).

Decision-makers of the economy are understandably also interested in the tendencies that can be seen in consumers' decisions and in what will be competitive products and technologies in the future (Lehota, 2004; Szakály, 2017). This outlook is especially exciting when we are witnessing a paradigm shift in several fields of the economy, coming from the changes in the consumer behaviour; previous decision-making patterns transform and force producers/service providers and dealers to adapt to the new phenomena (Törócsik, 2016).

In our paper, aware of the importance of the issue and keeping the complexity of its concept of approach, we focus on the emphasis of signs indicating new and innovative consumer behaviours. We concentrate on those megatrends that are the driving forces of transitions and that lead to the consequences of strikingly reconsidered consumer decisions nowadays (Hauser et al., 2015; Rützlers, 2018). We conflict elements of the expected processes with the facts and statistics, and with the relevant findings of our related representative primary research.

Accordingly, we examine current consumption data, the major trends influencing the food market, how important eating is for the Hungarian population, what main gastro-channels they use to get information and communication, and what attitudes the respective consumers' segments show.

\section{Material and methods}

Food and eating have always been more than simple intake of nutrients, it is not accidentally the object of the interest of academics from different areas (Forgács, 2004), but during its examination we must not forget about its basic function of satisfying biological needs. Evidently, as long as our physiological needs are not satisfied, we are unable to think of food culture and the aesthetics of foods, the sophisticated ingredients and the variations of the experience offered by eating (Pich, 2014). Food phenomena are not only analysed from the aspect of consumer behaviour (Törőcsik and Pál, 2014); academics of other disciplines look at e.g. the environmental impacts of food consumption (Kerekes and Csutora, 2012; Notarnicola et al., 2017; Wunderlich et al., 2018), but researches related to disgust have also been made (see e.g. Egolf et al., 2018). The topic of gastronomy has also caught a growing media attention, and in public conversations it is a reliable and neutral issue suitable for creating a contact with everyone (Balázs et al., 2012), which is interpreted by Kapitány and Kapitány (2013) as a new phenomenon of the new millennium. Recently, cooking at home has been appreciated, which is 
also supported by the media, as it is promoted not only by academic researchers but also by celebrities and opinion leaders. The growing popularity of cooking at home is closely related to healthy nutrition (Smith Taillie, 2018). Of course, another side of the issue has also been growing in popularity: foods ordered to our homes, street food and the consumption of convenience foods.

When talking about our thinking of food, several groups of influencing factors must be examined, whose correlations from the aspect of the consumer are described by a complicated matrix. Eating is influenced by ingredients (access, supply, transport etc.), possibilities offered by technology (deep freezing, simmering, baking etc.), the knowledge possessed by a community (family tuition, books, shows, courses etc.), and also the lifestyle of a group that is also typical of the individuals, due to their membership in the group. These broad categories shape eating culture that can be examined at the level of groups and individuals, completing all this with the related emotions.

Taking different indicators into consideration allows us to find several variations, evoking useful or only interesting behaviours in this huge market.

\section{Food consumption data}

Looking at data series of longer periods of food consumption reveals that both quantitative and structural changes are taking place simultaneously in Hungary (Table 1), the saturation of the consumption of cereals and carbohydrates is finished, while the consumption of vegetables and foods is still increasing (Vetóné, 2014).

The examination of the consumption data of Hungarian households over the last ten years, using the data published by the HCSO, reveals a rather mixed picture. Let us focus on the data relevant for us from the 2017 HCSO data on the expenditure of the households and their living conditions, reflecting the findings of the consumption of 7485 households questioned (HCSO, 2017). Figure 1 demonstrates a considerable restructuring from 2010 to 2016, and within this the proportion of expenditure on foods increased from $22.8 \%$ to $24.1 \%$.

For the interpretation of the data we must remember that the consumption of households significantly decreased in quantity as an effect of the crisis starting in 2008, the effects of which were still palpable in the early 2010s, i.e. consumption was stagnating until 2012 and started to grow afterwards. In addition to the quantitative changes we could also see changes in the composition of the consumption. 
Table 1: A comparison of European and Hungarian trends (1990-2007)

\begin{tabular}{|c|c|c|c|c|}
\hline & \multicolumn{2}{|c|}{ Europe } & \multicolumn{2}{|c|}{ Hungary } \\
\hline $\begin{array}{l}\text { Consumptio } \\
\mathrm{n} \\
\text { category }\end{array}$ & $\begin{array}{c}\text { Quantitative } \\
\text { change } \\
\left(\mathrm{kg} \mathrm{person}^{-1} \text { year }^{-1}\right)\end{array}$ & $\begin{array}{l}\text { Proportion from } \\
\text { total of food } \\
\text { consumption } \\
(\%)\end{array}$ & $\begin{array}{c}\text { Quantitative } \\
\text { change } \\
\text { (kg person }{ }^{-1} \text { year- }^{-} \\
\left.{ }^{1}\right)\end{array}$ & $\begin{array}{l}\text { Proportion } \\
\text { from total of } \\
\text { food } \\
\text { consumption } \\
(\%)\end{array}$ \\
\hline Cereals & $\begin{array}{c}138 \mathrm{~kg} \rightarrow 131 \mathrm{~kg} \\
\text { decreasing }\end{array}$ & $\begin{array}{c}19.3 \% \rightarrow 17.6 \% \\
\text { decreasing }\end{array}$ & $\begin{array}{c}110 \mathrm{~kg} \rightarrow 88 \mathrm{~kg} \\
\text { decreasing }\end{array}$ & $\begin{array}{c}16 \% \rightarrow 13 \% \\
\text { decreasing }\end{array}$ \\
\hline Meat & $\begin{array}{l}81 \mathrm{~kg} \text { on the } \\
\text { average, but the } \\
\text { tendency is increase }\end{array}$ & $\begin{array}{c}11 \%, \text { no } \\
\text { change/increasing }\end{array}$ & $\begin{array}{c}73 \mathrm{~kg} \rightarrow 63 \mathrm{~kg} \\
\text { decreasing }\end{array}$ & $\begin{array}{l}9 \%-11 \%, \\
\text { no change }\end{array}$ \\
\hline $\begin{array}{l}\text { Dairy } \\
\text { products }\end{array}$ & $\begin{array}{l}210 \mathrm{~kg} \rightarrow 221 \mathrm{~kg} \\
\text { increasing }\end{array}$ & $29 \%$, no change & $\begin{array}{c}169 \mathrm{~kg} \rightarrow 163 \mathrm{~kg} \\
\text { decreasing }\end{array}$ & $25 \%$, no change \\
\hline Fat & $28.5 \mathrm{~kg}$, no change & $3.8 \%$, no change & $\begin{array}{c}38.6 \mathrm{~kg} \rightarrow 37.4 \mathrm{~kg} \\
\text { decreasing }\end{array}$ & $6 \%$, no change \\
\hline Fruits & $\begin{array}{l}73 \mathrm{~kg} \rightarrow 93 \mathrm{~kg}, \\
\text { increasing }\end{array}$ & $\begin{array}{l}10.2 \% \rightarrow 12.4 \%, \\
\text { increasing }\end{array}$ & $155 \mathrm{~kg} \rightarrow 194 \mathrm{~kg}$ & $23 \% \rightarrow 31 \%$ \\
\hline Vegetables & $\begin{array}{l}107 \mathrm{~kg} \rightarrow 117 \mathrm{~kg} \\
\text { increasing }\end{array}$ & $\begin{array}{l}15 \% \rightarrow 15,6 \% \\
\text { increasing }\end{array}$ & increasing & 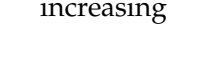 \\
\hline $\begin{array}{l}\text { Proportion of } \\
\text { import } \\
\text { products in } \\
\text { consumption }\end{array}$ & $\begin{array}{c}\text { meat }+120 \% \\
\text { cereals }+83 \% \\
\text { vegetables }+174 \%\end{array}$ & increasing & increasing & $\begin{array}{c}\text { 7-10\% } \rightarrow 30 \%, \\
\text { increasing }\end{array}$ \\
\hline
\end{tabular}

Figure 1: Breakdown of the expenses of households, 2010-2016

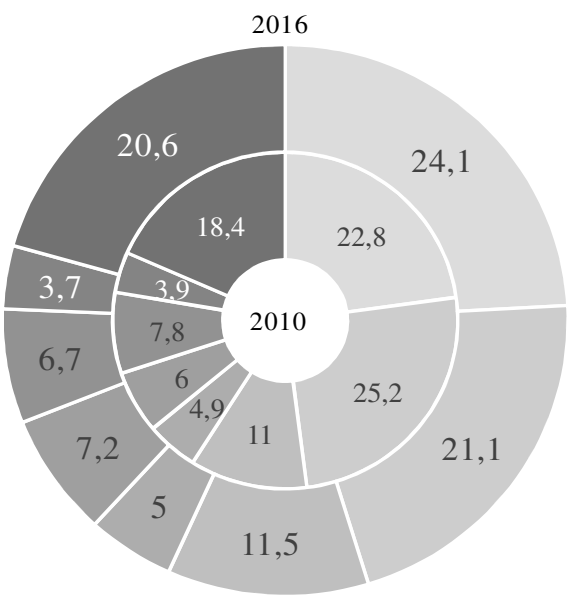

Foods and non-alcoholic beverages

- Housekeeping, energy of housing

- Transportation

" Health

- Telecommunication

- Culture and entertainment

- Catering and accommodation services

- Other

Note: edited by the authors, Source: HCSO (2017) 
"The amount of the consumption of certain foods by the households is decreasing, which also reflects the qualitative change in the consumption habits. From 2010 to 2016 for example the quantity of bread consumed in a household decreased by 7.5 kilograms, but the purchase of crescents, rolls and other bakery products grew by 4.7 kilograms. Similarly, during the period examined the population consumed less animal fat (by 1.8 kilograms), but the consumption of vegetable oil and olive oil grew by 1 litre. In 2016, the costs of eating outside the household were HUF 34.5 thousand per person, half of this was meals in the workplace, school and kindergarten; the other half was meals in catering industry facilities and the consumption of beverages. The amounts paid in catering facilities have tripled since the start of the new millennium, and have grown to one and half since 2010. The most dynamic growth could be seen in the amount of per person expenditure on foods delivered home." (HCSO, 2017) Naturally, the respective groups show different consumption patterns within these general data (Bakucs et al., 2017).

These processes have brought about a critical situation for the market actors in production and sales, and not all of them have been able to successfully adapt to the changes. In comparison to the changes caused by the crisis, the recent changes in the demand seem less drastic, but they are still a continuous challenge, not last due to the pressure by the consumers who come up with ever mode diverse, always new demands.

Trend impacts in the food market

It is an evident decision then to also involve the trend connections of food/eating in our examinations, as the knowledge of these bears the chance of market success as well as it promotes the understanding of the decisions of consumers. In order to make right decisions we have to understand the operation of recent megatrends (Bosshart and Frick, 2003; Horx, 2015). We can state that within the megatrends, trends promote acceleration/speeding up, technological changes and rationality, a certain concentration of which is already hard to tolerate for people, and so after a while they are seeking the chance of slowing (themselves) down, showing a preference for the solutions of the counter-trend. Slowing down (the world and ourselves) contains emotional elements, even with some possible romantic touch, some affection for idyllic, human-scale "former life", but its recent manifestation is already adapted to the new frameworks. The dynamism of megatrends is given by the movements of trends and counter-trends, and they also give thrill and ever new business opportunities with the new combinations. The harmony of the two directions leads to stability; this may secure balance in societies (Hauser, 2016). As the frameworks of this study do not allow the detailed discussion of the respective megatrends that we have identified (for more 
information see Törőcsik and Csapó, 2018), only references are made to them.

The issue of food is comprehensible in the cross-section of any megatrend; it is visible in everyday life, in cutting edge industrial practice that foods show up in the interconnections of different megatrends, especially in the field of health, body, ethical considerations, digitalisation, eco-paradigm and transparency (Törőcsik, 2014). In our examination a new feature to be highlighted is that in food industry and food trade, actions related both to trends (innovations with ICT technologies, convenience) and counter-trends (sustainability, sharing) can lead to successful solutions. We can see a growing popularity of bio-, vegetarian and vegan products, ones that can be consumed by people with food intolerance, and of fair trade products. We can also see a growing expectation by sustainability and transparency, impulses basically coming from the direction of slowing down. Functional foods are becoming important, as are digital developments related to eating, food porno is spreading fast, and all these promote acceleration. Of course only a smaller proportion of the population reacts to the total of the trend effects with modified shopping habits, but the new trends are more and more palpably filtering into the decisions made by the majority of consumers. This (among other things) makes it important to see what is typical of the Hungarian consumers, how much these phenomena are present in their everyday lives.

\section{Research method}

The basis of the primary research of our examination was a personal questionnaire survey including 2001 persons, conducted in April and May 2018 in order to analyse the behaviour and the opinion of the Hungarian population, among other things, as regards their eating habits. The questionnaire was representative of the Hungarian population aged 1574 by gender, age groups (10-year intervals) and the region of the place of residence. The processing of the results took place with mathematicalstatistical methodology, and also using the SPSS software for analysing data. During the processing of the findings we also made demographic background examinations, the findings of these are used to demonstrate the statistically justifiable deviations. The variables included in the analyses were as follows: gender, generations, health condition, level of schooling, subjective evaluation of the income positions, settlement category of the place of residence, and economic activity.

The project allowing the primary research is implemented with the support of the European Union, in co-financing of the European Social Fund, see EFOP-3.6.1-16-2016-00004 project called "Comprehensive 
developments at the University of Pécs for the implementation of intelligent specialisation".

\section{Results and discussion}

The importance of foods, gastro-media behaviour

The first question that we asked of the respondents in our research was how important role food had in their lives. The respondents had to tell us their opinions on a Likert scale ranging from 1 to 10 . The results indicate that food is important in the lives of the respondents, as $78 \%$ of them agreed with this statement to an extent above 5. We could not find significant differences across generations, whereas we think we found weak correlations according to settlement category, health condition, schooling and gender. We can say that the ones who more typically agreed with this statement were inhabitants of large villages or cities with county rank, and also people with college degree and secondary grammar school education. Respondents less typically agreeing with this statements included ones with more limited financial incomes, i.e. the ones struggling with problems of day-to-day living, and also those who stated that their incomes were not enough for a mere living, or those who reported to have definitely bad health condition. In the lives of male respondents, food plays a more important role than in the lives of their female counterparts, but the disparity was a few percent, only.

We also examined how much respondents liked eating and cooking. Our finding is that respondents more typically agreed with the statement that they liked eating (with 66 percent indicating values of 4 and 5), and also the fact that they were fond of cooking (with 53 percent indicating values of 4 and 5) on a Likert scale ranging from 1 to 5 . We did not find significant correlations between how much somebody liked eating and what school education they had. We found weak correlations according to gender, generations, the settlement category of the place of residence, income level evaluated, and health condition. The results demonstrate a higher level of agreement with this statement by males, the young, the dwellers of the capital city or large villages, and a lower level of agreement by those with low income levels and having definitely bad health condition.

As regards whether somebody likes cooking and how they judge their own income levels, no significant correlation was found. We observed a weak correlation in accordance with generations, the settlement category of the place of residence, school education and the condition of the respondent's health. We can state that the older somebody is, the more they agreed with the statement "I like cooking" (among the elderly respondents, the proportion of those indicating value 4 or 5 was $62 \%$ ). This statement 
was rather agreed with by those possessing secondary grammar school or higher qualifications, and also those whose health condition was in some respect, or in all respects, a limiting factor in their own opinion.

People less typically agreeing with this statement were the inhabitants of the capital city, more typically agreeing were those living in smaller towns. A medium strong correlation (Cramer's V value=0.443) was detected between gender and whether they like cooking, i.e. results indicated that a much higher proportion of women agreed with this statement.

We also asked respondents about illnesses that prevented them from eating any food. Almost $13.24 \%$ of respondents (265 persons) declared that they had some disease of this kind, and 3\% did not wish to answer this question. Another question of ours was whether they had some special eating restriction, if they followed any special diet. What we found is that slightly more people follow special diets than the number of those who have special diseases preventing them from food consumption, but this value was still low, only made $14.23 \%$ (285 persons) in the sample. Most of those who are restricted from eating just anything and follow special diet omit sugar from their foods (almost 50\%), but many of our respondents do not eat white flour $(28.6 \%)$, or are on a general slimming diet $(25.5 \%)$.

Besides the diets listed above, a relatively large proportion of respondents mentioned other things, which that indicates the complex nature of the issue and the diversity of diets currently followed. We also wanted to know if those respondents who followed special diets had some illnesses. Findings show that $68 \%$ of those who are on a diet (194 persons) suffer from diseases influencing their food consumption. This reveals, on the one hand, that the rest follows special diets not due to illnesses but some other reasons, and we can say, on the other hand, that there are some respondents who, despite suffering from some disease, do not follow any kind of diet.

Dealing with gastronomy may be a recreational activity and a form of pastime, but this - primarily - content consumption does not have the same significance for each of the consumers' groups. We conducted a Kmeans cluster analysis in order to examine whether it was possible to define groups different from each other on the basis of media consumption and involvement in gastronomy. During the processing of our database, within the total of the sample $(n=2001)$ we could identify three clusters (Figure 2). The first one is called "simply eaters", the second one is the "modern gastro-maniacs", while the third group was dubbed as "traditional gastro-maniacs". 
Figure 2. Clusters defined on the basis of gastronomy-related media consumption and gastro-involvement

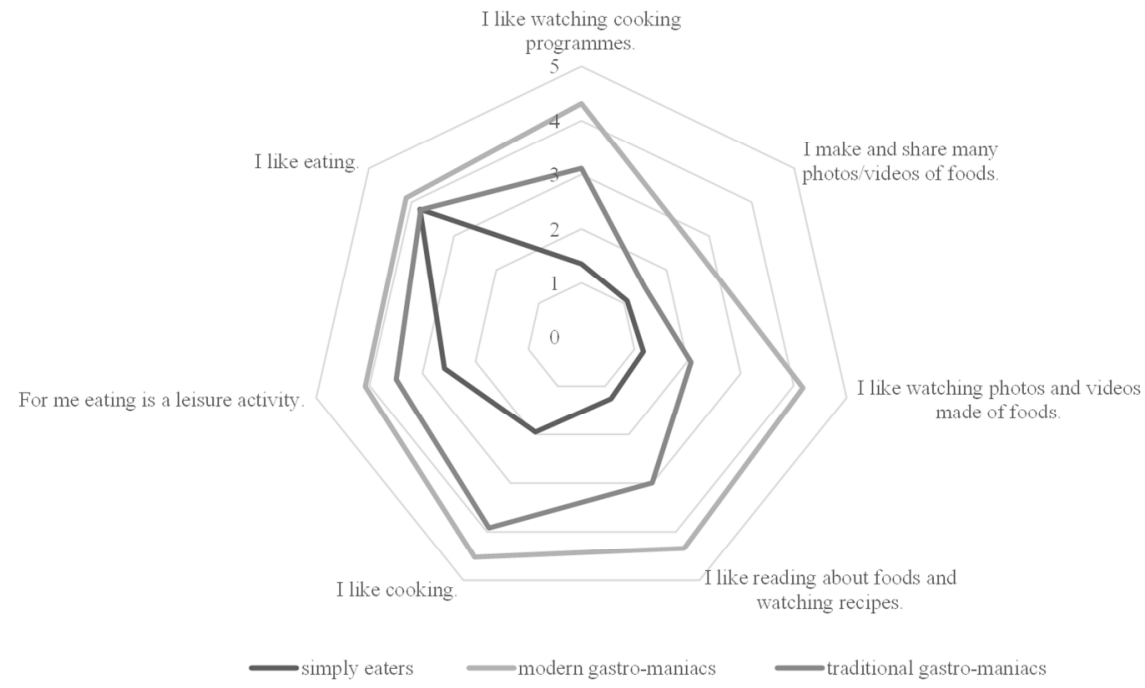

Note: edited by the authors

Members of the cluster of simply eaters (who are $35 \%$ of the sample) show a below-average interest in the consumption of media, eating is of medium importance for them, and their interest in gastronomy is no more than simply the love of eating. The group is characterised by dominance of males, and with above-average proportion of those with skilled worker qualification, residents of the capital city, the young and the middle-aged. Members of the cluster of modern gastro-maniacs (25\%) show a broad interest in gastronomy, be that eating, cooking or watching cooking programmes. Members also showed an above-average agreement as regarded activities taken as more modern, such as watching and sharing food videos. Within the group we can see an overrepresentation of those with secondary grammar school qualification and a below-average proportion of those who had only completed 8 classes of primary school.

They are a typically urban group. As regards generation groups, middle-aged are over-represented. The largest group (40\%) is made by traditional gastro-maniacs who show an average interest in the consumption of traditional media content related to eating (watching cooking programmes, reading recipes), and a below-average interest in consuming modern media content (watching and sharing food photos/videos). They like eating and cooking. It is a group with female dominance and typically with urban place of residence, with an overrepresentation of elderly members. 


\section{Segments defined by eating orientation}

As another important element of our empirical research, we looked at, with cluster and factor analysis, the possibility of identifying consumer segments of the present Hungarian society aged 15-74 on the basis of their attitude to eating. The factor analysis was made for the following variables: the importance of eating ( 1 variable, 10 grade scale), attitudes towards cooking (6 variables, 5 grade scales), attitudes towards eating habits and gastronomy (15 variables, 5 grade scales). Using 19 scale variables 5 factors were identified which, as latent variables, describe the attitude of the respondents of the survey towards eating and gastronomy: the love of cooking; sophistication and variety; scarcity; routine/usual; and importance of eating. Attitude statements related to the factors and their weights are demonstrated in Table 2.

Table 2. Result of the cluster analysis: 5 factors of eating-related issues, according to the rotated component matrix

\begin{tabular}{|c|c|c|c|c|c|c|}
\hline \multicolumn{7}{|c|}{ Rotated Component Matrixa } \\
\hline & K & & & & & $\begin{array}{l}\text { Specifi- } \\
\text { cations of } \\
\text { factors }\end{array}$ \\
\hline & 1 & 2 & 3 & 4 & 5 & \\
\hline I like reading about foods and watching recipes. & .884 & & & & & \\
\hline I like watching cooking programmes. & .836 & & & & & The love \\
\hline I like watching photos and videos made of foods. & .813 & & & & & of \\
\hline I like cooking. & .740 & & & & & cooking \\
\hline I make and share many photos/videos of foods. & .591 & & & & & \\
\hline $\begin{array}{l}\text { It is very important for me that food is served in an } \\
\text { elegant way. }\end{array}$ & & 685 & & & & \\
\hline My diet is varied. & & .669 & & & & \\
\hline $\begin{array}{l}\text { I consume foods made from high quality } \\
\text { ingredients. }\end{array}$ & & .668 & & & & $\begin{array}{l}\text { Sophisti- } \\
\text { cation, }\end{array}$ \\
\hline I have a preference for local products. & & 642 & & .361 & & variety \\
\hline I like eating in company. & & .624 & & & & \\
\hline I like the cuisines of other countries. & & .530 & & -.531 & & \\
\hline I often eat in catering facilities or order food. & & .448 & & -.487 & & \\
\hline $\begin{array}{l}\text { It often happens that I cannot eat enough, because } \\
\text { I cannot afford it. }\end{array}$ & & & .781 & & & \\
\hline I often get food from others. & & & .751 & & & Scarcity \\
\hline What I can afford is the cheapest foods. & & & .735 & & & \\
\hline I like eating familiar dishes. & & & & .743 & & Routine/ \\
\hline The Hungarian cuisine is the real one. & & & & .722 & & usual \\
\hline How important role does eating have in your life? & & & & & .810 & Impor- \\
\hline For me eating is a leisure activity. & 345 & & & & .765 & eating \\
\hline
\end{tabular}

Note: edited by the authors; Extraction Method: Principal Component Analysis; Rotation Method: Varimax with Kaiser Normalisation; a. Rotation converged in 7 iterations. 
For the identification of consumer segments dominant for our research topic a cluster analysis was conducted, using these factors, with a $\mathrm{K}$ means cluster analysis. The result of this analysis was the distinction of 5 clusters of the Hungarian population aged 15-74 $(n=1975)$. The correlations of the respective clusters and factors are demonstrated in Figure 3.

Figure 3. Cluster features on the basis of the factors examined

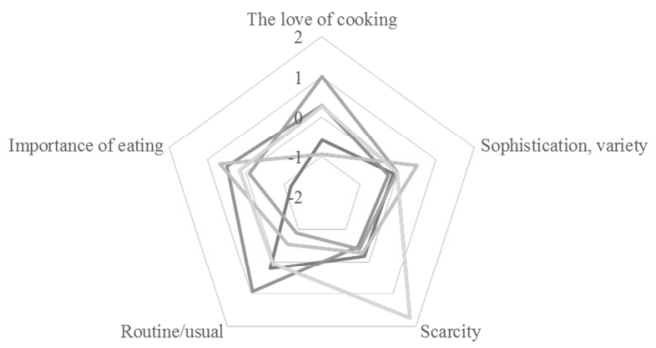

Note: edited by the authors

The respective clusters were interpreted on the basis of their attitudes demonstrated by factors, and of their demographic background. As regards the respective demographic attributes, the following show significant differences among the clusters: gender $(\chi 2=209.712 ; \lambda=0.132$, $\varphi=0.326$, Cramer-V=0.326; $\mathrm{p}<0.000)$, generations $(\chi 2=195.151 ; \lambda=0.039$, $\varphi=0.314$, Cramer-V=0.222; $\mathrm{p}<0.000)$, settlement category of the place of residence $(\chi 2=49.923 ; \lambda=0.006, \quad \varphi=0.159$, Cramer-V=0.079; $\mathrm{p}<0.000)$, marital status $(\chi 2=172.552 ; \lambda=0.048, \varphi=0.296$, Cramer-V=0.148; $p<0.000)$, and subjective judgement of income position $(\chi 2=182.465 ; \lambda=0.070$, $\varphi=0.304$, Cramer-V=0.152; $\mathrm{p}<0.000)$. In case of highest school education $(\chi 2=119.917 ; \lambda=0.0396, \varphi=0.246, C$ ramer-V=0.142; $\mathrm{p}<0.000)$ and economic activity $(\chi 2=287.431 ; \lambda=0.055, \varphi=0.382$, Cramer-V=0.191; $\mathrm{p}<0.000)$ it was the response Does not know/Does not answer where the minimum expected cardinality of 5 for the respective values was not met.

The clusters identified by the analyses above are characterised by the following features:

The indifferent (21.6\%): Members of this segment are less interested in cooking, they are not so much fond of sophistication and their enthusiasm for traditional foods is not particularly high, either. They are not likely to suffer from financial problems. In this group males are above-average represented; group members are older and have primary school education. Their incomes are limited, just enough for a living. As 
regards economic activity, pensioners are in an above-average proportion among them.

Elderly people looking for traditional tastes (23.9\%): Members of this cluster show an outstanding interest in traditional foods, eating is important for them, but sophistication is not typical for them at all. Their incomes do not particularly limit their possibilities. Their interest in cooking is not outstanding. Looking at their demographic background we can see an above-average proportion of people over 60, females, married and widows/widowers. Their highest school education is typically only primary school. An above-average proportion of them indicated that their incomes were hardly enough for a living. A significant share of them is pensioners.

Trained housewives (18.9\%): Their interest in cooking is outstanding, in comparison with the other clusters. They do not show affinity to traditional foods, at the same time they strive for sophistication - even though there are segments that they lag behind in this issue. Financial considerations are not typical for the members of this group. The cluster shows a definite dominance of females. The elderly are below-average represented. They are more likely to live in countryside towns and cities.

Their highest school education is at least secondary school. Their income positions are good; they are even able to save smaller or larger sums of money. They typically have intellectual professions.

Young male gourmets (19.2\%): The member of this segment consider eating as important, but their interest in cooking is by far less intensive.

Striving for sophistication and variety is most typical for this group, but they do not show any particular interest in traditional cuisine. The group is definitely of masculine character. As regards their age, they are more typically young, and residents of the capital city have a proportion slightly above the average. Their highest qualification is at least secondary school, but highly schooled members are also strongly represented among them. As regards their marital status, singles and those living in non-marital partnership have shares above the average, and their income positions are the best among all segments. As regards their economic activity, above-average proportions of them learn or are active earners (both white- and blue-collars).

Self-caterers falling behind $(16.3 \%)$ : What is most typical of this group is the limitations of their financial means. Their interest in traditional foods is measurable, and at the same time they strive for sophistication as well.

Their interest in cooking is not outstanding, but they are likely to regularly practice that as part of the daily routine. In this segment, the smallest one of all, the proportion of males and females is balanced.

There is not one generation that is dominant in the age composition, and the share of those living in the smallest settlements has a somewhat 
above-average proportion. As regards the highest school qualification, many of them indicated primary school, only. They have financial problems; their incomes are enough for a day-to-day living at the best.

The proportion of blue collars among them is above the average, as is the share of unemployed.

\section{Conclusions - (acknowledgements)}

After the crisis, food consumption has started to grow again recently in Hungary, but with a changed composition and with more and more differentiated demands appearing.

We have found that in the lives of the Hungarian adult population eating has an admittedly important role. The importance of eating is more definitely approved by inhabitants of large villages and cities with county rank, and also by those who have college degree and secondary grammar school certificate. Interestingly, eating is less important for those struggling with problems of day-to-day living, and also for those who have reported to have definitely bad health condition. Eating is slightly more important in the lives of male respondents than in the lives of their female counterparts. The reasons should definitely be discovered why eating is valued as less important by those that have problems of living and struggle with illnesses - one would expect them to find it as an issue of vital importance. Another ex-post research should be devoted to the issue why males more intensively agree with the importance of eating, although stereotypes would make us expect that of women.

Media contents related to gastronomy are not interesting at all for 35\% of respondents, $40 \%$ of them have a preference for traditional media, while $25 \%$ like new media solutions as well.

We have identified segments on the basis of attitude to eating, among which the groups of trained housewives and young male gourmets, i.e. approximately $38 \%$ of all respondents, are standing our positively.

Trained housewives show an active interest and like creating, whereas young male gourmets are active in consumption. Other analyses in the future can reveal whether making further, smaller groups of them will demonstrate trend groups that are statistically also verifiable.

We found that approximately $14 \%$ of respondents are on a slimming diet or follow a special diet. The ones that follow a special diet mentioned in a relatively large proportion, in addition to slimming diets, other diets - this demonstrates the diversity of habits and concepts. This $14 \%$ also contains patterns of eating behaviour related to trends.

It is a definitely new phenomenon that many extend their concept chosen for the change of their eating habits to other product areas as well, like clothing or tourism. Just think of clothes, shoes or car accessories 
chosen by the vegans, and slow tourism. It has become typical to create a life philosophy from the consumption of foods.

On the whole we can summarise that the consumption of foods is more and more shaped by the impacts of trends, which forces food industry actors to carry out an analysis of the trends before making their longer term decisions, keeping in mind that the behaviour of the majority of consumers is evidently not characterised by the following of the trends.

\section{References}

Bakucs Z.-Benedek Zs.-Kiss V. (2017): A magyar háztartások élelmiszerfogyasztásának alakulása a 2007 és 2009 közötti pénzügyi válság tükrében. Statisztikai Szemle. 10: 1023-103.

Balázs G.-Balázs L.-Veszelszki Á. (2012): Gasztroszemiotika - Az étkezés jelei. Magyar szemiotikai tanulmányok 27. kötet. MSZT - Eötvös Kiadó. Budapest.

Bosshart, D.-Frick, K. (2003): Trendreport Megatrends Basic. Rüschlikon.

Egolf, A.-Siegrist, M.-Hartmann, C. (2018): How people's food disgust sensitivity shapes their eating and food behaviour. Appetite. 127: 28-36.

Forgács A. (2004): Az evés lélektana. Akadémiai Kiadó. Budapest.

Hauser, M. (2016): Trends im Konsumverhalten. Wirtschaftspolitische Blätter. 4: 785-795.

Hauser, M.-Bosshart, D.-Höchli, B.-Borek, J.-Muller, Ch. (2015): European Food Trends Report. GDI Studien. Rüschlikon.

HCSO (2017): A háztartások életszínvonala. https://www.ksh.hu/docs/hun/ xftp/idoszaki/hazteletszinv/hazteletszinv16.pdf Downloaded on 11 July 2018

Horx, M. (2015): Zukunft wagen: Über den klugen Umgang mit dem Unvorhersehbaren. Pantheon Verlag. München.

Kapitány Á.-Kapitány G. (2013): Látható és láthatatlan világok az ezredfordulón. Typotex Kiadó. Budapest.

Karmasin, H. (2001): Die geheime Botschaft unserer Speisen. Bastei Lübbe. Wien.

Kerekes S.-Csutora M. (szerk.) (2012): Fenntartható fogyasztás? Trendek és lehetôségek Magyarországon. OTKA 68647 sz. kutatás eredményei. AULA Kiadó. Budapest.

Lehota J. (2004): Az élelmiszerfogyasztói magatartás hazai és nemzetközi trendjei. Élelmiszer Táplálkozás Marketing. 1. 1/2: 7-13.

Notarnicola, B.-Tassielli, G.-Renzulli, P. A.-Castellani, V.-Sala, S. (2017): Environmental impacts of food consumption in Europe. Journal of Cleaner Production. 140: 753-765.

Pich A. (2014): Armut, Arbeitslosigkeit und Konsum: Theoretische Grundlagen und empirische Ergebnisse zum Konsumentenverhalten in Armut und Arbeitslosigkeit. Kovac Dr. Verlag. Hamburg.

Rützlers, H. (2018): Foodreport 2019. Zukunftsinstitut GmbH. Frankfurt.

Smith Taillie, L. (2018): Who's cooking? Trends in US home food preparation by gender, education, and race/ethnicity from 2003 to 2016. Nutrition Journal. 17: 41. 
Szakály Z. (szerk.) (2017): Élelmiszer-marketing. Akadémiai Kiadó. Budapest.

Törőcsik M. (2014): Az ételfogyasztás megatrend kapcsolódásai. Táplálkozásmarketing. 1. 1-2: 19-27.

Törőcsik M. (2016): A fogyasztói magatartás új tendenciái. Vezetéstudomány. 47: 19-25.

Törőcsik M.-Csapó J. (2018): Fogyasztói trendek hatása a turizmusra. [In: Csapó J. et al. (szerk.) Generációk a turizmusban. I. Nemzetközi Turizmusmarketing Konferencia - Tanulmánykötet.] 2018. 03. 23. Pécsi Tudományegyetem Közgazdaságtudományi Kar (PTE KTK). Pécs. 8-22.

Törőcsik M.-Pál E. (2014): Az étel, étkezés a mai mindennapokban: a reggeli. [In: Bódi J. et al. (szerk.) A mindennapi élet mint téma és mint keret.] 2014. 10. 1718. PTE Kommunikáció- és Médiatudományi Tanszék. Gondolat. BudapestPécs. 98-119.

Vetôné Mózner Zs. (2014): A fenntartható élelmiszer-fogyasztás lehetőségei. Magyar Tudomány. 6: 730-739.

Wunderlich, S. M.-Martinez, N. M. (2018): Conserving natural resources through food loss reduction: Production \& consumption stages of the food supply chain. International Soil and Water Conservation Research. https:/ /doi.org/10.1016/j.iswcr.2018.06.002 Downloaded on 25 June 2018 